\title{
TRÊS TESES COMPARATIVAS ENTRE OS PENSAMENTOS DE WEBER E DE NIETZSCHE*
}

\section{Renarde Freire Nobre}

Há um fio condutor das teses que aqui serão apresentadas com intuito de comparação entre elementos do pensamento de Max Weber (18641921) e o de Friedrich Nietzsche (1844-1900). Trata-se da hipótese central do estranhamento, a qual perpassa todo o texto e é sustentada pelo combate permanente de idéias, perspectiva comparativa que, como se poderá bem notar, não exclui a busca das afinidades e de possíveis conciliações entre aspectos de idéias que, no fundamental, se mostram díspares. As as três teses serão expostas na seguinte seqüência: a primeira tratará do tema co-

* Agradeço aos pareceristas, não apenas pela indicação do texto para publicação, mas sobremaneira pela pertinência das sugestões, relativas tanto às idéias como à linguagem, as quais me induziram a uma cuidadosa revisão.

Artigo recebido em maio/2003

Aprovado em maio/2004 nhecimento, abarcando dois subitens - um que se refere ao "estatuto da verdade" e outro ao "estatuto da ciência" -; a segunda tratará do tema da dominação, igualmente central em ambos os pensamentos, mas que engloba pressuposições e recebe tratamentos bastante singulares em cada autor; e a terceira tese tratará do tema da tragédia, aplicado especialmente ao âmbito da cultura moderna.

\section{Primeira tese: sobre o conhecimento}

São muito distintas as concepções de conhecimento sustentadas por Weber e por Nietzsche. Este é um dos pontos de maior distanciamento entre os dois pensadores, o que não impede que também aí o sociólogo apresente algumas concordâncias com o filósofo que ele teria considerado, juntamente com Marx, um referente matricial para o pensamento moderno. ${ }^{1}$ A distância que os sepa- 
ra na tematização do conhecimento não tem a ver pura e simplesmente com a distinção entre um pensamento científico e um pensamento filosófico, dado que o primeiro se ocuparia mais com produção do conhecimento e teria preocupações metodológicas e, o segundo, mais com a justificação do conhecimento e teria preocupações epistemológicas. Tal distinção tem certa aplicação, mas deve ser relativizada, em parte porque tanto Weber como Nietzsche se ocuparam com questões de fundamentação e de produção, mesmo que em graus variados.

A relevância da separação entre o pensamento científico weberiano e o pensamento filosófico nietzschiano melhor se define quando se trata da oposição entre uma concepção racionalista e uma concepção transracionalista de conhecimento. Essa distinção estabelece uma barreira definitiva entre Weber e Nietzsche quanto ao tema do conhecimento, para além de uma mera divisão de funções entre ciência e filosofia, a qual poderia sugerir, inclusive, uma complementaridade entre os autores, quando o que se vê, ao se examinar mais profundamente cada pensamento, é um forte estranhamento. Esta pode, então, ser melhor denominada como a diferenciação entre a racionalidade teórica weberiana e a transracionalidade vital nietzschiana.

Estritamente no que diz respeito às questões relativas ao conhecimento, pode-se sintetizar a diferença nos seguintes termos: enquanto a racionalidade teórica designa a busca do "conhecimento válido" e prescreve, para tal, o uso rigoroso de recursos lógicos formais (conceitos e juízos causais) voltados para a explicação e evidência empírica, a transracionalidade vital, por sua vez, designa a busca de um "conhecimento ativo" e prescreve, para tal, o uso expressivo de recursos estilísticos (tropos, adjetivos, entonações, humor etc.) voltados para a simbolização e assimilação psíquica. De um lado, o encontro entre formalismo e empiria, de outro, o encontro entre poesia e vida; de um lado, impessoalidade e neutralidade, de outro, pessoalidade e incorporação; de um lado, a reflexão, de outro, a inspiração.

Ainda assim, o leque das questões atinentes ao conhecimento continua muito aberto e impreciso.
Poder-se-ia, por exemplo, querer perscrutar o significado da distinção em termos das metodologias de investigação utilizadas pelos autores, ou em termos das linguagens e dos aspectos da escrita e do estilo, ou em termos da relação com a tradição filosófica como o kantismo, o positivismo e a hermenêutica, ou em termos da relação com a história, e tantas outras possibilidades. Sendo várias as direções que se poderia perseguir, escolheu-se, para as reflexões que se seguem, o seguinte mote: pensar a distinção no tocante ao conhecimento em termos das diferentes interpretações dos problemas da verdade e da ciência. Dito isso, passarei às considerações de tais problemas.

Nietzsche pressupõe uma acomodação de impulsos diferenciados no fundamento de tudo que reputamos "verídico", "evidente", "lógico" ou "verdadeiro". Os "jogos de forças" se dão em função de serem elas designadas como "vontade de potência", e a manifestação de uma vontade só pode se dar como potencialização em direção a outra vontade. Das relações de afetação mútua entre vontades, formam-se hierarquias e domínios conforme a intensidade das explorações e a qualidade das assimilações de forças. Ao sentido fundamental da hierarquia num jogo de forças Nietzsche chama de afeto de comando, cujo termo ele aplica especialmente à conformação, no homem, do caráter como corporeidade de forças. Quanto ao princípio de conformação dos afetos de comando, ele o chama de incorporação. Uma espiritualidade é feita de hierarquias e regida pelo princípio da incorporação, como toda a vida, daí a metaforização do espírito como um estômago (Nietzsche, 1992, \$230, p. 137). A sensibilidade filosófica diz, então: "verdadeiro" é tudo aquilo que se encontra incorporado (Nietzsche, 2001, \$110, pp. 137-139), e digno é o espírito que ousa fazer as incorporações mais intensas, que é perpassado por grandes forças e grandes contradições.

Tudo que se considera serem "verdades", morais ou lógicas, mascara as diferenças e as contradições que as sustentam como perspectivas primárias. Os valores absolutos e as "verdades" são máscaras que ocultam conflitos, desajustes, desfigurações, descontinuidades, esquecimentos. $\mathrm{Na}$ pré-história do perdão cristão, há ressentimento; 
o homem bom é o masoquista cruel da má consciência; e "o curso dos pensamentos e inferências lógicas, em nosso cérebro atual, corresponde a um processo e a uma luta entre impulsos que, tomados separadamente, são todos muito ilógicos e injustos” (Idem, \$111, pp. 139-140). De modo geral, contra a metafísica - que o filósofo caracteriza como a "crença nas oposições de valor" - ele sustentou a tese de que um valor pode precisamente nascer do seu oposto (Nietzsche, 1992, \$2, p. 10). Como destruidor, Nietzsche foi um (des)codificador e o fez embaralhando e confundindo signos e significações. Quanto à crença no verdadeiro, o filósofo criou uma designação geral para o afeto de comando que a rege: vontade de verdade [Wille zur Wabrheit].

Pela interpretação nietzschiana da origem ilógica da lógica, todos os mecanismos a ela associados são falsamente tomados como "verdadeiros". São os casos da crença na "consciência", no "eu", na "causalidade", nas "leis", nas "substâncias", nas "idéias". Tem-se a ilusão de ser a lógica uma faculdade da mente humana, quer transcendental (Kant) quer histórica (Weber), à qual corresponderia um sujeito cognoscente; tem-se a ilusão de que uma coisa é causa de outra coisa, ou seja, que há entre as coisas relações lógicas; tem-se a ilusão de que há igualdade entre as coisas, ou, simplesmente, tem-se a ilusão de que existem "coisas". No caso da ciência, o raciocínio em termos de causa e efeito fere a arbitrariedade, a singularidade e a plasticidade que existem na produção de cada acontecimento e está intimamente ligada à propensão de se tratar dois ou muitos fenômenos como iguais.

Em termos gerais, a estratégia nietzschiana para dar conta do "estatuto da verdade" consistiu em retirá-lo do registro da epistemologia cientificista para inseri-lo nos registros da fisiologia e da psicologia. Se o "verdadeiro" não é o que é provado ou logicamente sustentado, mas o que é incorporado ou afetivamente produzido, significa que a verdade se refere à constituição dos corpos e dos espíritos como configurações de forças e suas figurações. Sabendo-se, de antemão, que a distinção entre corpo e espírito é tão-somente esquemática, porque um espírito é feito de incorporações e todo corpo é uma estrutura anímica. Nietzsche viu a psicologia como a arte de interpretação dos "tipos espirituais" como incorporações afetivas. Por exemplo, os tipos religiosos assimilam sob condições de "obstrução fisiológica" e produzem valorações morais idealistas; já os "espíritos livres" assimilam sob condições de "intensificação fisiológica" e produzem valorações práticas e artísticas.

Os novos registros da "verdade" operam sobre a noção de causalidade no sentido que Nietzsche preferirá, no lugar do esquema causa-efeito, o esquema dominação-submissão. Significa que, se queremos perscrutar a relação entre impulsos ou acontecimentos diferenciados, devemos perguntar pelo sentido do comando e das assimilações, não pelo sentido da causalidade e das conseqüências. Isso porque uma coisa não diz nada sobre a sua causa, pois ela não é efeito de nada, mas tão-somente uma nova efetivação; o que reputamos necessidade e causa não passa de uma dedução colada àquilo que surgiu (Nietzsche, 2001, \$205, p. 173). Mais precisamente, o esquema causa-efeito é um perspectivismo estreito, demasiado humano, pois entre o que consideramos a causa e o que consideramos o efeito há uma miríade de vontades e atos que passam ao largo da consciência; daí o esquema causa-efeito ser tão-somente uma interpretação, um artifício, nunca uma efetiva explicação (Nietzsche, 1992, §21, pp. 26-28). Um sentido não provém de um outro, mas estabelece com os demais relações (hierarquizadas) de potência. Na verdade, o que há, o tempo todo, são relações, forças em ação, jogos de dominação e de submissão. Não se concebe uma situação de vazio de poderes, porque não há ausência de forças, e toda força é exercício de potência. Entre as forças ou os fenômenos de forças não há enlaces causais e lógicos, mas estratégicos e vitais.

Weber tem uma visão completamente distinta. Primariamente porque o seu pensamento sociológico procura operar de maneira rigorosa nos registros articulados da história e de uma metodologia racionalista. Cada um desses registro implica numa ruptura com a visão nietzschiana. Histórica é a perspectiva de se pensar as causas singulares das conformações sociais, do presente e do passado, as quais ganham autonomia cultural (sentido pró- 
prio) ante o registro natural dos impulsos nietzschianos. E racionalista é a perspectiva de se pensar os fenômenos sóciohistóricos quanto ao sentido e grau de coerência racional, o que envolve procedimentos lógicos que operam a despeito das irracionalidades. Não que Weber negue a existência de determinações corpóreas ou sentimentais, mas, por aqueles registros, para ele "verdadeiro" é tudo aquilo que pode ser logicamente sustentado e empiricamente validado. Em oposição formal ao princípio nietzschiano de incorporação, pelo qual o "verdadeiro" é apresentado como configurações de afetos, impulsos pré-conscientes e valores, o princípio weberiano de objetivação representa o "verdadeiro" como configuração de significações conscientes e de fatos verificáveis. Mais do que isso, a própria conquista de uma tal significação "científico-metodológica" para a verdade - pensada como enunciados submetidos a critérios lógicos, causais e empíricos - é um fato histórico, correspondente ao processo ocidental de racionalização e autonomização do intelecto, jamais uma faculdade transcendental (Kant) ou a uma crença enganosa (Nietzsche).

A lógica - pensada sob o signo da coerência e do universalismo argumentativo - tem seus registros históricos e corresponde a uma efetividade irredutível a fatores ilógicos. Não há a "origem da lógica" como acomodação tardia da luta de impulsos diferenciados, como quis Nietzsche; o que há é a formação histórica das categorias lógicas do pensamento científico, que carregam a sua autonomia, posto basearem-se em interesses conscientes específicos. A modernidade é o contexto histórico que sustenta esse parecer weberiano na medida em que é nela que se desenvolve a plena autonomia de uma lógica investigativa da realidade. O registro decisivo da lógica não é o ilógico, mas o histórico e o científico. Sendo a ciência moderna a realização mais significativa do pensamento lógico, a sua afirmação pode até ser pensada como uma coisa "tardia", mas não no sentido de ser um resultado secundário do movimento de impulsos diferenciados em luta, e sim no sentido de ser o resultado de um processo recente de objetivação do pensamento sob o signo da coerência. No parecer weberiano, as operações lógicas não são de modo algum enganosas e secundárias; elas são, ao contrário, as condições primárias de possibilidade da produção de verdades válidas. No caso do esquema causa-efeito aplicado ao mundo empírico, embora formal, ele não é uma ficção convencional, mas uma conquista intelectual com potencial de explicação dos cursos dos eventos. Ao contrário de Nietzsche, Weber aposta no método explicativo, mesmo que, no âmbito das ciências da cultura, o juízo seja sempre precedido do momento interpretativo. De modo geral, a intelectualização lógica reflete, em si, um processo de racionalização e um princípio de domínio.

Definitivamente, o que Weber quis dizer sobre a relação entre conhecimento e realidade no plano das ciências da cultura foi o seguinte: o fato de os homens se orientarem por valores e de essa orientação, em seu fundamento último, não ser passível de uma compreensão racional demonstra, sem dúvida, a impropriedade de se expressar em termos de uma "realidade em si" passível de ser conhecida. Disso não se deduz, todavia, que as orientações valorativas não possam se apresentar ou não existam como realidades concretas, mas apenas que o conhecimento válido das "configurações concretas de relações significativas" tem que ser, necessariamente, lógico-significativo. O que desencadeia a pesquisa é sempre um ponto de vista valorativo especificante do "real", o qual passa a obedecer um percurso lógico para sua validação objetiva. Mas o lógico, como condição formal de objetivação e validação, não refuta a noção do concreto ou do empiricamente dado. Há o válido e há o concreto.

Ao operar distinções entre o vivido e o efetivado, o intencionado e o concretizado, o escolhido e o conhecido, Weber afasta-se ainda mais do imaginário nietzschiano. É que Nietzsche recusara tais distinções. Por meio da noção de acontecimento do diferente, ele rejeita a idéia do coerentemente efetivado - como ilusão de que há racionalidades autônomas -, tanto quanto por meio da idéia de incorporação afirma que tudo que é da ordem do efetivo também é da ordem do vivido inconsciente. A separação weberiana entre um plano "supraempírico" [Überempirische] e um plano "empírico", entre o plano dos posicionamentos últimos de va- 
lor e o plano dos procedimentos concretos (Weber, 1991, p. 100), seria falaciosa porque supõe uma dualização da vida e abre espaço para a produção de um conhecimento supostamente purificado de ingerências irracionais, supostamente extrafisiológico, quando tudo na vida é figuração de jogos de forças e todo conhecimento é irracional e afetivamente motivado e sustentado.

Nietzsche e Weber, por certo, negam o real como dimensão absoluta. O que existe é inexoravelmente múltiplo, fluido e incompatível em seus sentidos mais profundos. Há, contudo, uma importante diferença. Weber concebeu uma dimensão empírica, e, embora ela só se ascenda à consciência de maneira ordenada e validada pela lógica formal, isso não lhe subtrai a condição de facticidade e não faz da coerência uma mera ilustração lógica. Nietzsche, por seu turno, desdenhava dos que acreditavam em fatos, em sentidos coerentes, em causa e efeito, em evidência empíricas, vendo tudo isso senão como efeito de interpretação, como demasiadamente humano e historicizado. Disso, temos a distinção entre uma concepção de conhecimento formal e aproximativo em relação ao concreto e uma concepção de conhecimento ativo e criador de "realidades".

O fundamental na epistemologia weberiana é o pressuposto de que a ciência é a validação lógica do concreto. A ciência não funda e não reproduz o concreto e nem é o concreto mera representação científica, com o que a pesquisa científica seria mera abstração; não por acaso, metodologicamente falando, o percurso lógico deságua na prova empírica. O que a ciência faz é dar validade ao concreto, e isso não é pouco, pois simplesmente ela o faz reconhecível. A verdade lógica é válida como modo de representação que ordena e confirma a ordem do possível.

Aqui, toca-se diretamente no problema do estatuto da ciência em Weber. Para ele, a ciência representa, para as consciências, a máxima evidência do concreto e do efetivado no plano da cultura. Demos a palavra a Weber:

Com os meios da nossa ciência, nada poderemos oferecer àquele que considere que essa verdade não tem valor, dado que a crença no valor da ver- dade científica é produto de determinadas culturas e, não, um dado da natureza. Mas o certo é que buscará em vão outra verdade que substitua a ciência naquilo que somente ela pode fornecer, isto é, conceitos e juízos que não constituem a realidade empírica nem podem reproduzi-la, mas que permitem ordená-la pelo pensamento de modo válido (Weber, 1991, p. 100, grifo do autor).

Como acontecimento cultural, a ciência tem o monopólio do proferimento da verdade válida.

Quanto à visão de Nietzsche da ciência ou, melhor ainda, da cientificidade moderna, o que falta à mesma - e a todo ascetismo ocidental - seria a "grande fé", o "grande amor', uma "meta além de si". A "meta" ascética é a crença no uno (o bem, a verdade, a justiça) e a conseqüente recusa do outro (o mal, a loucura, a injustiça), por isso ela se encontra no espaço de significação do "ser" e do "dever". Já a "meta do além de si" é radicalmente antiidealista e antimoral, como um estar "além do bem e do mal", além do "outro", interno e externo, como símbolo afirmativo do "devir", contra o "ser" e o "dever", e símbolo da leveza da criação contra o peso da obrigação. No caso da ciência, a obrigação da busca do "verdadeiro". A ciência como Quimera de "leão" e "camelo": diz não ao dogmatismo mas continua a carregar o fardo do ideal - busca da "verdade" e fidelidade à "realidade". A ciência se fecha numa meta, e não mostra a inocência da "criança" que diz sim ao devir. ${ }^{2}$

$\mathrm{Na}$ crítica à ciência, Nietzsche não esteve preocupado tanto em discutir o estatuto da verdade quanto em mostrar que a disposição e o sacrifício afetivo na busca da "verdade" - chamada de "objetiva", "lógica", "válida" - é um dos mais expressivos sintomas do niilismo, na sua variante passiva, o que se nota na prescrição à imparcialidade e à impessoalidade. Assim, onde não é simplesmente "a mais nova manifestação do ideal ascético",

[...] a ciência é hoje um esconderijo para toda espécie de desânimo, descrença, remorso, despectio sui [desprezo de si], má consciência - ela é a inquietude da ausência de ideal, o sofrimento pela falta do grande amor, a insatisfação por uma frugalidade involuntária... A ciência como meio de auto-aneste- 
sia: vocês conbecem isto? (Nietzsche, 1998, III, \$23, pp. 135-137).

Nietzsche se recusa, então, a direcionar a discussão do problema da verdade para o fórum da ciência e seus instrumentos de validação e objetivação, ou seja, para o fórum do entendimento racional. Isso significaria valorar o mais refinado disfarce ascético do intelectualismo, com o qual o homem "objetivo" acredita estar além do "bem e do mal". Acontece que ele não está, porque, embora a verdade não seja mais vista como absoluta e caminho para a paz ou para a felicidade, a disposição para a mesma é um sintoma de persistência das forças decadentes que vêm trançando a intricada teia das significações modernas. Como "valor", a verdade prescreve uma moralidade; como "sintomatologia", a valoração da verdade prescreve uma moral decadente, edificada sobre condições doentias, que caracteriza a modernidade e que Nietzsche quis superar.

Em que consiste o diagnóstico da decadência e em que sentido o valor da verdade é um problema moral? Nietzsche deu uma resposta decisiva, quando selou a decadência como impulso de se negar a vida e querer outro mundo, que se manifesta na prescrição de "não querer enganar os outros nem a si mesmo" (Nietzsche, 2001, \$344, pp. 234-236). A ciência avançou sobre a tradição e as certezas absolutas, o que a fez abandonar a esperança de "não querer deixar-se enganar", pois já aprendeu que as convicções podem ser muito mais perigosas e prejudiciais do que a dúvida e a desconfiança. Apesar dessa consciência antidogmática, Nietzsche se surpreende de os homens continuarem a "querer a verdade", quando a vida é feita de erros, desvios, desacertos, descontinuidades - algo que a própria recusa das convicções já demonstrava. Ele reagirá percebendo que a ciência só realizou uma crítica parcial da moral, só superou o niilismo mais tosco e ingênuo, mas não o niilismo tardio. Ela é um sintoma da decadência moral porque continua querendo o que não existe na vida, na natureza, na história; por isso, então, o diagnóstico "irônico": "vontade de verdade' bem poderia ser uma oculta vontade de morte". E, com isso, Nietzsche define a presença na ciência de um niilismo decadente ao lançá-la de vez em direção à velha "crença metafísica" que instaurou Deus como sendo "a verdade" e abriu caminho para a divinização do verdadeiro. As "crenças metafísicas" tomadas como o supra-sumo da decadência moral, e os valores que sobre elas repousam, como sintomatologias doentias.

No prefácio para $O$ nascimento da tragédia, escrito dezesseis anos depois do lançamento do livro, Nietzsche apresenta o "problema da ciência" como aquilo que ele aprendeu de novo. Ele não aprendeu apenas que o "problema da ciência não poderia ser reconhecido no terreno da ciência" - com o que concordará Weber -, mas, também, que era preciso "ver a ciência da ótica do artista e a arte, da ótica da vida". A arte rasga a teia conceitual, distrai a consciência racional e destrata dos seus principais disfarces. A cultura cientificista tem uma visão instrumental dos fenômenos e dos conhecimentos; os fenômenos servem a tal causa e o conhecimentos servem para tal causa. Uma visão artística dissolve a instrumentalidade e contempla os fenômenos e a obra como criação arbitrária e inútil. Para Nietzsche, a ciência protege-se dos riscos, por isso quer conhecer; a arte arrisca-se, por isso quer enganar. Weber não compactuou dessa conclusão de submeter o problema da ciência à apreciação artística ou qualquer uma outra que lhe seja exterior, recusandose, mesmo, a dar uma resposta ao problema da ciência, aceitando-o como uma irracionalidade última, uma pressuposição, uma fé. Para ele, as esferas definitivamente já se extraviaram umas das outras, já firmaram os seus domínios e demarcaram sua legalidade.

Para Nietzsche, porém, um fundamento, uma interrogação, uma pergunta, um problema, uma razão: tudo isso deve também ser avaliado, e é mais profundo um conhecimento que o faça. Uma interrogação já pode ser sintoma de uma ilusão. Ao mesmo tempo, e contra o racionalismo, os maiores conhecimentos podem se expressos como indagações e enigmas, como o que não é compreendido - mas perturba... Quanto a Weber, ele não quis avaliar os problemas e os fundamentos, mas tãosomente lhes dar consistência lógica para lhes entender o sentido e as motivações concretas. Vê-se 
bem essa diferença no caso da ciência. Weber concorda que a ciência trabalhe a partir de pressupostos e guarde, nisso, sua fundamentação irracional, mas ele toma isso como dado e não avalia a sua significação última; tudo porque, do ponto de vista científico - ou seja, lógico-empírico - não cabe discussões sobre pressupostos; só cabem discussões e avaliações (lógicas) de procedimentos e conexões coerentes de sentido. Weber não só não submete o científico a uma razão alheia, como procede a partir das suas premissas internas. Com Nietzsche, ao contrário, são principalmente os pressupostos que devem ser avaliados ou questionados de modo valorativo, pois, embora de raízes irracionais, eles se inscrevem na semiótica das forças. No caso da ciência, por exemplo, ele avaliará o pressuposto do valor da verdade como signo da tradição metafísica ocidental, de origem platônica e cristã.

Há mesmo um elo definitivo entre Weber e Nietzsche, que é o fato de ambos entenderem a dimensão do pensamento e da vida como um todo em termos, em última instância, de um compromisso de valor ou de uma "visão de mundo" (Weltanschauung). Mas, é exatamente nisso que está a razão principal do estranhamento, pois, na medida em que cada um firma um compromisso valorativo ou assume uma Weltanschaunng absolutamente inconciliável - por vezes, exatamente oposta - com a do outro, a compatibilidade se desfaz em si mesma como barreira intransponível entre as causas. As interpretações díspares da ciência - num caso, como "negação do mundo", no outro, como "afirmação do mundo", é uma ilustração precisa disso.

\section{Segunda tese: sobre poderes e dominações}

Uma afinidade pelo reconhecimento da cultura e da vida como campos de domínio e de luta é, sem dúvida, um ponto forte na relação entre Weber e Nietzsche. Ela pode ser expressa em dois sentidos: um primeiro - que se pode dizer analítico - diz respeito ao apontamento das formas e dos sentidos dos domínios nos estudos históricos, sociais ou filosóficos, com especial atenção aos poderes dominantes e modos de apropriação típicos da modernidade, fixando-se características e limites. Um segundo sentido - que se pode chamar ético - diz respeito ao posicionamento que cada autor julga o mais digno ante os poderes dominantes na contemporaneidade.

No tratamento desses dois sentidos, contudo, os autores se distanciam nas considerações dos poderes, tanto ao definirem a natureza última dos domínios - se de tipo vital e efetivo, como pensou Nietzsche, ou se de tipo histórico e efetivado, como analisou Weber -, como também ao definirem o posicionamento ante os poderes hegemônicos - se se trata da ousadia na constituição de novos domínios da subjetividade e de novas formações culturais, como quis Nietzsche, ou se se trata da inserção consciente e corajosa num determinado campo de domínio, com o reconhecimento das suas exigências e conseqüências, como pensou Weber.

Considerem-se as diferenças nos tratamentos conferidos ao sentido da apropriação, aplicável a ambos os autores, pois os domínios - quer vitais, quer histórico-culturais - envolvem sempre modos de apropriação ou de disposição sobre bens. Em Nietzsche, temos o princípio geral das forças que se apropriam de "territórios" e "elementos" de outras forças como modo de intensificação de potências, o que vale para todos os momentos ou as figurações de forças; mais precisamente, a efetivação de potências é sempre um modo de apropriação, de ocupação de espaços e criação de novas significações, porque destruir é condição imprescindível às estratégias de apropriação. Para Nietzsche, entre o homem e a vida, a consciência e a matéria, os sentimentos e as idéias, o social e o individual, o que há são diferenças de intensidade e de ritmo, de sentido e de complexidade nos processos de assimilação. Enfim, viver é, essencialmente, apropriarse; e a noção de incorporação expressa diretamente um sentido de apropriação.

No caso de Weber, temos o profeta que se apropria dos afetos, o sacerdote que se apropria dos instrumentos da graça, o Estado que se apropria da violência, a burocracia que se apropria das normas de administração; a instituição que se 
apropria dos instrumentos de execução das tarefas etc. Na verdade, os sujeitos dessas frases são, eles próprios, processos construídos como modos de apropriação. As relações sociais que interessaram a Weber eram as que se apresentavam explicitamente como modos de dominação, ou seja, em que as regularidades das condutas eram dependentes do funcionamento de uma fonte reconhecida de autoridade, em que há, pois, apropriação "legítima". Há mecanismos de apropriação no domínio de toda autoridade. Ao nuclear as relações sociais sob a temática da dominação, Weber aproxima-se sensivelmente do imaginário nietzschiano, e talvez tenha, em certo sentido, realizado o anseio do filósofo por uma sociologia das estruturas de dominação contra o positivismo francês e o utilitarismo inglês do seu tempo.

Todavia, a despeito desse forte ponto de contato, Weber manteve-se deliberadamente distante do sentido nietzschiano de incorporação, porque, para ele, o mesmo não se distinguia da "possessão" e da velha ilusão da plenitude ou da experiência do mundo como vivência íntima, ou, ainda, da vida como "grande obra de arte". Mas também porque, pensar a apropriação como incorporação implicava em dar atenção maior aos mecanismo psíquicos de assimilação e subjetivação, quando Weber dedicouse aos mecanismo sociais de extensão e objetivação dos sentidos humanos. Por isso, a noção de apropriação melhor se define como "poderes de disposição" (sobre bens, corpos, valores etc.), e não como "incorporação".

Um aspecto muito relevante das diferenças entre os autores sobre o tema é a singularidade radical dos mecanismos de apropriação e, conseqüentemente, do tipo de autoridade, que Weber verificou no contexto da modernidade. Diz respeito ao grau de impessoalidade na apropriação de importantes meios de dominação, que deixam de pertencer diretamente à pessoa da autoridade e passam a designar um "senhor" impessoal. E o fenômeno da institucionalização de meios impessoais de dominação social é mesmo a marca singularizante da modernidade. Nela, a autoridade político-administrativa não reporta mais aos atributos e aos privilégios pessoais; as pessoas que ocupam as posições de poder legítimo estão submeti- das aos mecanismos impessoais de domínio. Além do que, nas instituições formais, produz-se uma expropriação privada via institucionalização dos meios. A ciência, o exército, as fábricas, o Estado: em todas essas áreas verifica-se a concentração institucional dos recursos operacionais - tecnologias, armamentos, maquinário, repartições. É claro que continua a haver apropriações pessoais relevantes, seja em microrelações, seja nas grandes relações sociais no que elas ainda comportam de traços tradicionais ou carismáticos de autoridade, seja na economia aquisitiva privada. Não se trata, pois, da ausência absoluta de exercícios pessoais de poder, mas da sua limitação e até inexistência em situações de domínio formalmente legítimas e onde há a institucionalização dos recursos. De todo modo, como pensador que reconheceu a natureza objetiva e impessoal dos processos de apropriação que constituem a faceta mais institucional da modernidade, Weber foi muito mais íntimo de Marx do que de Nietzsche.

A idéia de uma sociabilidade fortemente embasada em referências impessoais nos leva à noção de "racionalismo de domínio do mundo", a qual constitui a interpretação weberiana geral da cultura moderna como um modo de vida fortemente referido às representações formais e ao cálculo instrumental. Só é possível falar em "racionalismo" em meio a uma variedade de processos racionalizadores e por conta de similitudes entre esses processos. Nesse sentido, a combinação de uma racionalidade formal com uma racionalidade instrumental é a base da convergência entre cursos de ações tão singulares e irredutíveis uns aos outros. As racionalizações são muito distintas enquanto refletem a dimensão de um posicionamento, enquanto se definem conforme suas significações últimas, base da sua legalidade própria [Eigengesetzlichkeit], mas são muito parecidas por comportarem a conjunção de um formalismo e um instrumentalismo. Isso só se aplica àquelas esferas que se situam no plano ordinário da cultura, onde prevalecem interesses conscientes e onde há uma intensa institucionalização das relações, como são os casos da economia capitalista, do Estado burocratizado, do direito formal e das ciências empíricas; é por esse plano, e somente por ele, que se 
pode aplicar à cultura moderna o epíteto "racionalismo de domínio do mundo".

Já na visão de Nietzsche, o que se reputa objetividade, impessoalidade, universalidade, como supostos atributos "exteriores" das esferas mais racionalizadas, é, na verdade, apenas uma disposição niilista dos espíritos fracos ou "escravos". Mais do que isso, a dedicação ao Estado, à economia e ao conhecimento técnico é uma grande ilusão e um "ridículo delírio" (Nietzsche, 1983, p. 177), como abandono de si e uma perigosa inclinação ao "nada". O filósofo aristocrático não lamenta que os "escravos" assim se dediquem aos "alvos inferiores" que consomem e despersonalizam o espírito, como o são as instituições que apenas servem à utilidade e à conservação, incluindo-se os funcionários da ciência. Ele acreditava, todavia, que os espíritos elevados poderiam se esquivar dessa dedicação e potencializarem suas forças em direção a alvos "superiores". Para isso, seria mesmo útil a escravidão. Os grandes homens têm que escapar do filisteísmo, do publicismo, do utilitarismo e do profissionalismo modernos. E Nietzsche afirma, não sem certa ironia: "Nosso século, que tanto fala de economia, é um esbanjador: esbanja o mais precioso, o espírito" (Idem, ibidem). O "espírito livre" deveria seguir na superação de si, livrando-se das disposições gregárias, não tanto para negar o "escravo" e o "pequeno", mas para afirmar o senhorio de si em sua maioridade psicológica, solitária, supragregária. Ao se referir ao caráter ascético e decadente dos valores modernos, o filósofo-médico sentenciou: "quem comigo neste ponto está em desacordo, eu o considero infectado... Mas o mundo inteiro está comigo em desacordo" (Nietzsche, 1995 , p. 80). Então, no bojo de sua purificação pessoal, desejou, para a cultura, um novo futuro, uma nova elite, um posicionamento social para além da moralidade gregária.

Apesar de não ser um sociólogo, como Weber, ou até mesmo conferir um papel secundário às demandas coletivas, certamente a vida social figura como muito importante para compreensão do mundo em Nietzsche, como a mais decisiva perspectiva de acomodação do homem como espécie gregária. A vida gregária é apenas uma perspectiva entre outras, ela não define a natureza do homem mas, sem dúvida, representa a condição da maioria. Viver em sociedade é, fundamentalmente, estar sob a coação de sentidos comuns, é viver conforme os outros, as regras e as normas comuns, é, afinal, não ser soberano. O social é uma acomodação de forças à qual tendem os tipos escravos, aqueles que dependem do "outro" como referente de reconhecimento de si (e o que seria a ação social weberiana, como orientação pela conduta imaginada ou real do(s) "outro(s)", senão um comportamento reativo nos termos do julgamento nietzschiano?). Os nobres podem constituir autoridades e relação sociais, mas uma alma nobre é, essencialmente, distinta e especial, inclusive perante os seus congêneres.

A relação dos "senhores" com a sociabilidade caracteriza-se pela submissão e instrumentalização das relações sociais e dos escravos em nome de fins culturais mais elevados, o que implica em não se misturar nem ter compaixão pelos "pobres coitados" dos dominados. Sobre as "ovelhas", as "aves de rapina" dizem a si mesmas: "nós nada temos contra essas boas ovelhas, pelo contrário, nós as amamos: nada mais delicioso que uma tenra ovelhinha". Moral da história: toda força tem que se exercer como tal (Nietzsche, 1998, I, \$13, pp. 35-37). Seu instinto é o da distinção, e o social que se caracteriza pela perspectiva nobre é uma figuração mais primária da natureza egoísta dos impulsos vitais, como ilustrado pelo período em que a justiça senhorial se baseou na crueldade e na diferenciação entre "bom" e "ruim", ao invés de "bom" e "mau". Já o social da perspectiva escrava, como instinto gregário e moralizante, é feito de resíduos de forças - tal como um conceito é o resíduo de uma metáfora intuitiva -, correspondendo a um estágio de assimilação tardio e secundário; fruto de processos de obstrução fisiológica e de desvio das potências cruéis para dentro - o que levou à formação da "má consciência" (Idem, II dissertação). São os espíritos mais elevados quem, de fato, pode sofrer com a doença em que se tornou o homem, a norma, a sociedade etc., pois têm saúde para reagir com repugnância, e tal repulsa já é sinal de uma relativa afirmação de vida, de um pathos de distância. Os escravos 
referenciam-se no comum e na norma, os nobres, na distinção e na soberania.

Feitas essas considerações, elas nos sugerem que a tematização nietzschiana da idéia de dominação difere da perspectiva weberiana por duas razões basicamente: o filósofo opera com a noção de incorporação e, portanto, pensa a constituição dos tipos espirituais de domínio como parâmetro para avaliação dos tipos societários; e a interpretação do sentido da dominação tem um caráter valorativo, ou seja, toma um tipo como parâmetro superior. Com isso, tem-se em Nietzsche a primazia do traço psicológico sobre os traços sociológico e mesmo histórico, e a primazia da avaliação conforme valores sobre a avaliação lógica.

Nietzsche quis dotar sua filosofia de uma sapiência "médica", analisando as perspectivas humanas como sintomatologias de disposições fisiológicas, tanto quanto quis fazer da fisiologia uma psicologia, considerando o corpóreo como transfiguração anímica de afetos. Psicologia e fisiologia se cruzam porque o que está em jogo é uma leitura da espiritualização como disposições afetivas transfiguradas. A psicologia diagnostica. A fronteira entre os saberes dilui-se no intercâmbio dos signos e dos significados. Ou: o pensamento nietzschiano exercita-se como licença poética de se embaralhar signos e significados. ${ }^{3}$ Toda a perspectiva filosófica de Nietzsche se aplica, de modo especial, ao estudo dos dois tipos psicológicos de homens: o escravo e o senhor. O escravo é o tipo fisiologicamente obstruído, para quem as "medicações" se produzem no interior da própria lógica da fraqueza, que não atingem as causas, mas apenas os sintomas da doença, como são os casos da "curas" sacerdotal e socrática (Idem, III, \$17, pp. 119123). O senhor é um tipo fisiologicamente aberto, o que o faz corajoso e capaz de incorporações saudáveis; nele, a doença é estranha, casualidade, nunca um pathos, e advém do contato descuidado com os inferiores. Quando molestado pelas perspectivas fracas, apresenta saúde para reagir.

A doença de um e a saúde de outro podem, então, ser diagnosticadas pelo estudo dos valores ou, o que dá no mesmo, na semiótica dos afetos. De um lado, há o escravo, que tem no signo do "mau" a sua criação primária, mais original e au- têntica, o qual diz respeito ao "outro" mais forte e dominador. Nisso há sinal de ressentimento, reatividade, obstrução. De outro, há o senhor, que tem no signo do "ruim" - que se refere ao "outro" uma criação secundária e posterior, evidenciandose um caráter alegre, ativo e desobstruído, que gera uma moralidade baseada na veneração de si como tipo heróico e "bom" (Idem, I dissertação). $\mathrm{Na}$ visão nietzschiana, a disposição para a vida, seja boa ou má, é, antes de tudo, corporal, e toda moral é uma interpretação que reporta a disposições fisiológicas. Fisiologia entendida, é bom frisar, não como redução ao corpo físico-químico, mas como corporeidade que só pode ser apreendida como espiritualização, ou mais precisamente, como sintomatologias anímicas. O que distingue as estirpes e as personalidades nobres é precisamente uma digestão mais profunda a ponto de se saber cuidar da saúde. Porém, para eles, que sofrem de multidão e de mansidão, há o perigo do nojo do homem. "A visão do homem agora cansa - o que é hoje o niilismo, se não isto?... Estamos cansados do homem...", afirma Nietzsche. Como lógica dos cuidados que tomou para que o cansaço em relação ao homem não contaminasse o espírito ao ponto de se fazer cansaço com a própria vida, foi que Nietzsche aspirou à "superação do homem" - na verdade, do homem moderno, doente, domesticado e moralizado -, a fim de afirmar-se um novo tipo de homem, que o filósofo chamou de Übermensch. ${ }^{4} \mathrm{E}$, diante de uma modernidade em que os espíritos aristocráticos não tinham mais lugar, Nietzsche desejou que o sentido do Übermensch fosse incorporado pelos filósofos e espírito mais elevados, capazes que são de construir domínios nobres, ao que o autor denominou a "grande política", ou os "legisladores do futuro", ou a "autêntica cultura".

A visão das relações cotidianas e institucionalizadas, do Estado e da economia como "alvos inferiores e não totalmente indispensáveis", e a avaliação da dedicação dos homens a tais relações como um "grande e ridículo delírio", refletem uma concepção que insere as questões últimas do espírito e da cultura acima das questões da civilização. Daí a certeza de Nietzsche de que os espíritos singulares e soberanos poderiam se cultivar 
independentemente da normalidade e da legitimidade social, assim como a cultura mais elevada poderia sobreviver ao Estado, ao capitalismo e a todas as perspectivas demasiadamente modernas e desencantadas. Para ele, se quisermos ser precisos com o sentido mais autêntico da idéia de cultura, veremos que o moderno não a comporta, pois é mais um amálgama anárquico de coisas, pessoas e ações sem singularidade e profundidade, articulados de modo fundamentalmente instrumental, sem a presença, portanto, das codificações que distinguem uma comunidade e, no interior desta, uma elite temida e venerada em seus atos.

Pelo que foi exposto do pensamento nietzschiano, vê-se claramente onde não é possível acordo com Weber, pois será precisamente nas avaliações e nas expectativas do filósofo que este último verá ilusão e delírio. Porque, para o sociólogo historiador, o espírito está imbricado nas relações e nas formações socioculturais, e a resposta pessoal ao problema dos sentidos só pode se dar na consideração de tais relações e formações, como exercício de escolhas e renúncias conscientes. O que o filósofo considerou "alvos inferiores e não totalmente indispensáveis" tornava-se, em Weber, fins culturais cultivados como objetividades históricas, que, uma vez estruturados sobre um arsenal de meios necessários à orientação das ações, ganham autonomia e significação universal. Para Weber, não há mais lugar para "a cultura" superior ou "a personalidade" plena; ambas foram fragmentadas, e a integridade maior do espírito reflexivo consistia, a partir de então, em encarar de frente o destino histórico no qual se encontra submerso.

Nietzsche continuou a crer no espírito "criador de valores", para além dos desígnios da história e do projeto civilizatório "humanista"; Weber declarou a inevitabilidade da "servidão" aos valores historicamente situados, ao mesmo tempo em que viu a criação de novos valores especificada como tarefa de uma esfera situada no interior do cosmo cultural cultivado - a política. Ambos os autores descobriram a solidão na subjetivação do homem sem-Deus, mas um procurou vivê-la como extemporaneidade, e o outro, como contemporaneidade.
Vou aqui recorrer a uma análise de Norbert Elias (1997) pelo quanto nos auxilia no entendimento do estranhamento "ético" entre nossos dois autores. Ainda no século XIX, segundo Elias, os alemães se distinguiam dos franceses e dos ingleses por manterem-se na tradição da Kultur, que designava tanto a supremacia das questões mais elevadas do espírito, traçadas nos planos artístico, intelectual, moral e religioso, como os problemas práticos do homem de ação, traçados nos planos econômico e político, evidenciandose a recusa dos setores médios mais cultos de imiscuírem-se nos assuntos práticos do governo e nos negócios (Idem). Em contrapartida, o que se verificava na França e na Inglaterra era uma forte interação entre burguesia e nobreza, particularmente no sentido da participação político-administrativa da primeira. Assim, ao invés da noção de Kultur, prevalecia a noção de Civilization, quando "não se opõe ao homem civilizado um modelo humano radicalmente diferente, como o faz a Intelligentsia burguesa alemã com o termo gebildeter Mensch [homem instruído] e com a idéia de "personalidade"” (Idem, p. 55).

Essa distinção apresentada por Elias muito esclarece sobre os diferentes posicionamentos de Nietzsche e de Weber. Enquanto este aceitou os desígnios da civilização e sua pletora de interesses racionais, com o inevitável efeito de fragmentação e limitação das personalidades, tendo também participado de funções políticas junto ao Império, o filósofo manteve-se atrelado à tradição mais aristocrática de uma intelectualidade que via na vida ordinária e na prática dos interesses mais imediatos modos de contaminação da alma, daí a manutenção de uma concepção de cultura e de destino espiritual acima dos poderes civilizatórios, bem como a esperança de cultivo de uma personalidade soberana e distinta. Weber, como cientista, aspirou a um conhecimento que auxiliasse nas tomadas de decisão, e, como político, discutiu os problemas do seu tempo e fez proposições para a correta direção política, em especial perante o futuro da nação alemã; Nietzsche, na contramão disso, aspirou a um conhecimento valorativo e que expressasse tomadas de decisão, ao mesmo tempo em que se declarou antipolítico e antinacionalista. 
É verdade que Weber, na medida em que também nutria um desejo de distinção da espiritualidade, concordava, com Nietzsche, que as rotinas e os vínculos institucionais ferem a soberania do espírito e que as almas mais excelsas devem aprofundar suas questões para além das superficialidades e dos prazeres cotidianos. A diferença na avaliação é que, para o sociólogo o espírito estava definitivamente transformado, como impossibilidade de conquistar a plenitude e a soberania da personalidade; ao mesmo tempo, a dedicação corajosa do homem a um "deus" ou "demônio", mesmo sabidamente histórico e impessoal, é a maneira possível de se engrandecer e singularizar a relação com os fins socialmente cultivados. Weber enfrenta o "consumo do espírito", fazendo-o reflexivo sobre as condições que envolvem a sua presença na cultura, em busca de um posicionamento responsável e consciente. Se seguirmos a análise de Ringer, veremos que Weber fazia parte dos "mandarins modernizantes", os quais

[...] propunham-se encarar os fatos, aceitar que algumas facetas da vida moderna são inevitáveis ou mesmo desejáveis, procurando ao mesmo tempo abrandar seus aspectos mais acidentais e menos toleráveis. Essa atitude levou-os a controlar sua reação emocional no macro ambiente, a manter um ideal heróico de clareza racional perante a tragédia (2000, p. 159).

Nietzsche, ao contrário, opõe-se francamente aos tempos modernos, distanciando-se das perspectivas impessoais e das objetivações institucionais e lançando-se na busca de metas rigorosamente pessoais. Ele estaria mais próximo daqueles que Ringer nomeia "mandarins conservadores". Se, diante da "maquinaria social" ou das "técnicas de vida", vimos que o sociólogo defende a dignidade da inserção crítica na história moderna como modo de o homem "consciente" encontrar o sentido do seu ser e do seu fazer, quanto ao filósofo, ele defende a dignidade da solidão e do distanciamento da história moderna como modo de o espírito "ativo" superar tudo que lhe consome a singularidade. A "maquinaria social" e a "benção do trabalho" têm o mesmo sentido do apaziguamen- to místico da alma - a saber, livrar os fracos do infortúnio e da tristeza de se sentir fraco, obstruído, dependente -, mas apenas o fazem com sinais trocados. E, de modo mais amplo, a principal ameaça do processo civilizatório é mesmo os seus efeitos devastadores sobre os comandos mais pessoais. Daí, o desafio:

Serão vocês cúmplices da atual loucura das nações, que querem sobretudo produzir o máximo possível e tornar-se o mais ricas possível? Deveriam, isso sim, apresentar-lhe a contrapartida: as enormes somas de valor interior que são lançadas fora por um objetivo assim exterior! (Nietzsche, 2004, \$206, pp. 151-152, grifo do autor).

Os dois pensadores almejaram a sabedoria, o cultivo de si e a impressão, em seus atos, de um traço de si; mas, se em Nietzsche trata-se de uma sabedoria vital, do cultivo de uma natureza pulsional e de um traço de caráter, em Weber tratase de uma sabedoria reflexiva, do cultivo de uma vocação íntegra e de um "traço profissional". Do ponto de vista nietzschiano, a perspectiva weberiana é um inevitável e decadente "renunciar-se a si mesmo"; do ponto de vista weberiano, a perspectiva nietzschiana é um inevitável e romântico "renunciar-se às exigências do momento". E porque afirmam "mundos" diferentes é que são, cada qual na visão radical do outro, proponentes de algum tipo de "fuga".

\section{Terceira tese: sobre as tragédias}

As respostas "éticas" díspares remetem a uma imagem comum da vida ou da cultura trágicas. Todavia, as diferenças no tratamento do tema dos poderes e das dominações, bem como as ênfases dadas ora à cultura (Weber) ora à vida (Nietzsche) fazem com que a "imagem comum" se despedace em visões bem distintas. Comecemos por Nietzsche que, afinal, foi o único dos dois pensadores que efetivamente debruçou-se sobre o tema da tragédia.

Com Nietzsche, temos a tragédia essencial da vida pensada como encontro de forças inauditas, 
em especial, embates entre forças ascendentes e forças descendentes. Ele ilustrou as lutas por meio de diferentes figurações: Zaratustra em relação aos "últimos homens", o Übermensch em relação às sombras de Deus, o espírito livre em relação às "crenças metafísicas”, Napoleão em relação à Europa liberal e democrática, o dionisíaco em relação ao cristão, a alegria em face do desencanto, o próprio Nietzsche diante dos alemães. Para o filósofo-psicólogo, a tragédia da vida ou da cultura era, necessariamente, a sua tragédia pessoal, não no sentido de a alma ser maior do que a vida ou a cultura, mas da estilização de um caráter peculiar, superior e irredutível, via experimentação dos terremotos impulsivos e das contradições culturais.

"O grande e o pequeno pertencem à vida": a aceitação dessa idéia fez estremecer a alma de Zaratustra quando este convalescia da luta contra a "serpente" do niilismo. Na verdade, eram duas as suas angústias: "Demasiado pequeno, o maior! Esse era o meu fastio do homem! E o eterno retorno [ewige Wiederkunft] também do menor! Esse era o meu fastio de toda a existência!" (Nietzsche, 1998a, p. 225). O maior é o sentido da ascendência e, o menor, o seu oposto. Vencer os fastios: em relação à vida, amando-a, em relação ao homem cultivado, superando-o. Nietzsche procurou desfazer uma angústia na outra, erigindo o gesto de afirmação incondicional da vida [amor fati] como signo da "maioridade" ascendente. (Se em Kant o termo maioridade é sinônimo de liberdade para o exercício das potencialidades universais da razão, o seu emprego, em Nietzsche, é sinônimo de saúde pulsional e senso de distinção.) Trágica é a condição do homem perpassado "pelo maior e pelo menor", e mais trágica ainda é a grandeza ética de se afirmar "o maior e o menor", eternamente.

A tragédia que Nietzsche reivindica para si é tipicamente dionisíaca, a qual procurara entender já no seu livro de partida, O nascimento da tragédia, mas que só veio de fato a assimilar alguns anos mais tarde, após muitas vivências e incorporações. Na autocrítica que escreveu para o livro, ele reconheceu-se, ali, como um jovem discípulo de Dionísio, cujo nome, porém, aparecia impresso como um ponto de interrogação. Somente de- pois foi que ele veio a se reconhecer um discípulo afirmativo, quando se sentiu suficientemente leve para a alegria e o prazer que distinguem o dionisíaco. A "maioridade" do jovem discípulo teria sido atingida por perigosas experiências de auto-superação e de destruição criadora. De modo especial, viu-se liberto das corrupções modernas, que ainda estavam no seu primeiro livro, especialmente a sedução pelo alemão, seja na consolidação do Reich, seja na música wagneriana. Em O nascimento da tragédia, a despeito das críticas à base da tradição moderna, ainda havia uma impotência de se compreender decididamente o dionisíaco. A luta contra o niilismo decadente, expresso na compaixão e no fastio contemporâneos, foi precisamente a grande batalha do herói trágico nietzschiano, quando então ele pode declarar, na voz de Zaratustra: "Esta coroa do ridente, esta coroa grinalda-de-rosas: a vós, meus irmãos, eu vos atiro esta coroa! O riso eu declarei santo: vós, homens superiores, aprendei - a rir!". Dionísio - a divindade da embriaguez, da loucura e do riso - foi a derradeira assinatura exclamativa de Nietzsche.

O estilo final que ele imprimiu ao seu caráter remete à visão da vida como vontade de potência e, como tal, sinônimo de vontade de mais vida. A vida como atividade criadora, pura imanência de potências edificadoras de formas e momentos, sempre essencialmente isso, quer no forte quer no fraco, quer na saúde quer na doença, quer no clássico quer no moderno, quer no senhor quer no escravo. Essa visão é decisiva para que Zaratustra possa superar o fastio; sobre ela é que se alicerça o sentimento de afirmação do eterno retorno da vida. A vida como uma plástica de potências criadoras constitui, para Nietzsche, o seu desafio e a sua alegria mais profunda, a imagem última no seu "vaso de Pandora", cujo mistério se revela no espírito como amor fati. É este o sentimento que guiará - qual o "manobreiro" weberiano - os "trilhos" que levam Zaratustra a superar o perigo do fastio pela vida. A vida não deve ser julgada, muito menos lamentada e caluniada, porque ela é pura inocência, pura vontade, pura potência. O que Nietzsche se permite, e até mesmo se obriga, é perguntar pelas perspectivas huma- 
nas como sintomas, ou seja, se elas, como manifestação de potências, evidenciam fraqueza ou pujança, decadência ou ascensão, obstrução ou incorporação, doença ou saúde. Em tudo há potência, mas as potências têm intensidades e sentidos diferenciados.

Mas como poderia, efetivamente, uma "vontade de mais vida" exprimir-se como decadência ou vontade de nada e de morte? Por um lado, é preciso entender que o sentido "para o nada" não está na vontade em si - até porque esta não existe -, mas na figuração das forças; neste caso, ele pode indicar um domínio de potências enfraquecidas ou uma anarquia das mesmas. Em ambas as situações um só signo: o da desvitalização e da decadência. Historicamente falando, isso pode provir da mistura de raças ou classes muito heterogêneas (a Europa moderna), um imigração inadequada de um agrupamento (os hindus na Índia), velhice e cansaço de uma raça (pessimismo parisiense de 1850), um erro na dieta (alcoolismo na Idade Média), um afluxo de doenças (os alemães após a Guerra dos Trinta Anos) (Nietzsche, 1998, III, \$17, pp. 119-123). Em todos esses exemplos, vigora a carência - nunca a ausência - de potência. O filósofo perscruta os fenômenos e as personalidades como sintomatologias de impulsos vitais, indicando-lhe o sentido fundamental de doença ou de saúde. Por outro lado, é preciso entender que o "sentido de morte" ou a condição doentia dos domínios de forças é necessariamente um diagnóstico perspectivista, que provém de uma outra referência espiritual de domínio de forças, mais saudável e abundante, capaz de reagir aos sinais de fraqueza e doença. Talvez possa se concluir sobre a diferença pontuando-se que, quanto ao sentido, os fortes são ativos e os fracos, reativos; e, quanto à intensidade, a abundância é o atributo da força, enquanto a falta, o atributo da fraqueza.

Com Weber, temos a tragédia moderna dos valores como politeísmo das divindades impessoais, o que a faz tipicamente "socrática", pois referida aos homens e suas cultivações conscientes. É o estranhamento entre os valores cultivados, a distinção das conexões de sentidos organizadas como institucionalidades socioculturais, a luta dos "deuses" culturais. O trágico está no hiato de sen- tidos que se vê entre as grandes conexões significativas, o qual impõe à alma o desafio da escolha. A consciência plena da tragédia da cultura diz respeito à compreensão humana da inserção num universo conflituoso de significações que são autônomas e inconciliáveis, fazendo da cultura um universo "sem-sentido". Tal compreensão só se faz possível no âmbito de uma modernidade prenhe de racionalizações, e encontra, na ciência, a sua melhor representação, como a única esfera cultural capaz de, a partir do exame das grandes significações, apontar para o abismo entre os valores e sobre eles refletir com rigoroso distanciamento. A perspectiva científica - de se olhar diretamente para as questões últimas associadas às cultivações culturais e suas conseqüências inevitáveis - é o fruto mais moderno, e também o mais amargo, da "árvore do conhecimento".

Comparativamente, vemos que a tragédia é igualmente pensada por Nietzsche e por Weber a partir do entendimento da vida ou da cultura moderna como uma multiplicidade de forças que não se entendem e não podem formar uma unidade em seus sentidos últimos. Para Weber, trata-se da multiplicidade de domínios que se autonomizaram, como campos de significações irredutíveis uns aos outros, alguns com significado e validez universal (Weber, 1995, p. 315). Para Nietzsche, trata-se da multiplicidade de forças hierarquizadas conforme sentidos de comando; entre as forças não há entendimento nem anarquia, há comandos. A hierarquização significa, fundamentalmente, a onipresença de jogos de forças definidos pela lógica das intensidades. Quanto à multiplicidade weberiana das "autonomias" que não se conciliam, Nietzsche também a percebera na modernidade, mas a rejeitou como uma relação anárquica, uma paralisia das vontades, um estado doentio; e, diferentemente de Weber, a fragmentação não derivava de uma suposta autonomização das potências, mas da ausência de afetos de comando.

Weber, por sua vez, não viu hierarquia nem anarquia: para ele, o que as autonomizações evidenciavam era a ausência de uma coerência de sentidos, quer moral quer lógica, entre as esferas culturais. As potências, como astros autônomos, 
não orbitavam em torno de um "astro" Deus desencantado e esquecido, mas, sim, em torno de um "buraco negro" desprovido de significação. O cientista do desencantamento resignou-se com o entendimento de que há uma zona vazia de valores, de poderes, de sentido - e buscou retirar, dessa certeza, a sua integridade, ou seja, "o sentido do seu ser e do seu fazer". Diferentemente, Nietzsche entendeu o vazio e o deserto dos valores como uma interpretação equivocada, produto de forças decadentes, que alimenta a disposição humana para o impessoalidade e a passividade, enquanto as forças ascendentes afirmam hierarquias e distinções, recriando continuamente sentidos e domínios, precisamente porque são abundantes e não admitem o "vazio". E, deste embate dos pensamentos, mais uma vez, o fulcro do estranhamento.

\section{NOTAS}

1 Conforme o relato de Eduard Baumgarten sobre uma declaração informal de Weber a estudantes (1964, pp. 554-555).

2 Sobre o camelo, o leão e a criança ver Assim falou Zaratustra, "Das três metamorfoses".

3 O experimento literário de Zaratustra talvez seja a realização máxima do princípio de que o espírito filosófico só é efetivamente livre quando concede a si mesmo a liberdade da criação lingüística.

4 Habitualmente, a expressão Übermensch tem sido vertida para o português como "super-homem". Como esta tradução pode sugerir uma interpretação "humana, demasiado humana" do sentido original do termo, prefiro a tradução como "além do homem", que respeita mais diretamente o sentido fundamental de "superação". Para justificativa dessa opção, reporto o leitor à nota de Rubens Rodrigues Torres Filho, em Nietzsche (coleção Os Pensadores), pp. 228-229.

5 Em relação aos valores de Nietzsche, o termo $p a$ thos é mais conveniente de ser empregado do que a noção de "ética". O próprio filósofo deu-nos a deixa para essa opção quando esclareceu que a sua preferência pelos "hábitos breves" e pelas vi- vências pulsionais, mais intensas e transitórias, indica um pathos, ao invés de um ethos (FW, \$317).

\section{BIBLIOGRAFIA}

BAUMGARTEN, Eduard. (1964), Max Weber Werk und Person. Tübingen, J. C. B. Mohr.

ELIAS, Norbert. (1997), Os alemães: a luta pelo poder e a evolução do habitus nos séculos $X I X$ e XX. Rio de Janeiro, Jorge Zahar.

NIETZSCHE, Friedrich. (1983), Nietzsche (coleção Os Pensadores). São Paulo, Victor Civita. (1992), Além do bem e do mal. São Paulo, Cia das Letras.

(1995), Ecce Homo. São Paulo, Cia das Letras.

(1998), Genealogia da Moral. São Paulo, Cia das Letras.

(1998a), Assim falou Zaratustra. Rio de Janeiro, Bertrand Brasil.

. (2001), A Gaia ciência. São Paulo, Cia das Letras.

. (2004), Aurora. São Paulo, Cia das Letras.

RINGER, Fritz K. (2000), O declínio dos mandarins alemães. São Paulo, Edusp.

WEBER, Max. (1991), Schriften zur Wissenschaftslebre. Stuttgart, Reclam.

(1995), Schriften Zur Soziologie. Stuttgart, Reclam. 


\section{TRÊS TESES COMPARATIVAS TROIS THẼSES COMPARATI- ENTRE OS PENSAMENTOS DE VES ENTRE LES PENSÉES DE WEBER E DE NIETZSCHE WEBER ET DE NIETZSCHE}

Renarde Freire Nobre

\section{Palavras-chave}

Conhecimento; Ciência; Verdade; Dominação; Tragédia cultural.

Este artigo exibe três teses a respeito da relação entre o pensamento de Friedrich Nietzsche (1844-1900) e o de Max Weber (1864-1921), sob o signo geral do estranhamento entre os autores quanto aos pressupostos e algumas abordagens importantes. A primeira tese trata do tema do conhecimento, em especial os problemas de estatuto da verdade e da ciência; a segunda trata do tema dos poderes e das dominações; e a terceira, do tema da tragédia no seio da cultura moderna.
Renarde Freire Nobre

\section{Mots-clés}

Savoir; Science; Vérité; Domination; Tragédie culturelle.

Cet article propose trois thèses sur le rapport entre les pensées de Friedrich Nietzsche (18441900) et de Max Weber (18641921). Il a été conçu à partir des différences existantes entre les auteurs relatives aux présupposés et à certains abordages individuels. La première thèse aborde le thème du savoir, en particulier les problèmes du statut de la vérité et de la science. La seconde, celui des pouvoirs et des dominations; et la troisième, la tragédie au sein de la culture moderne.

\section{THREE COMPARATIVE THESES IN THE THOUGHTS OF WEBER AND NIETZSCHE}

Renarde Freire Nobre

\section{Keywords}

Knowledge; Science; Truth; Domination; Cultural tragedy.

The article deals with three theses regarding the thought of Friedrich Nietzsche (1844-1900) and Max Weber (1864-1921), under the general rubrics of estrangement between the two authors regarding presuppositions and some important approaches. The first thesis deals with the theme of knowledge, especially the problems related to the statute of truth and science; the second one deals with the themes of power and domination; and the third one deals with the theme of tragedy in modern culture. 